\title{
Localization of the cotyledon reserves of Theobroma grandiflorum (Willd. ex Spreng.) K. Schum., T. subincanum Mart., T. bicolor Bonpl. and their analogies with $T$. cacao $\mathrm{L}$.
}

\author{
MARIA HELENA MARTINI ${ }^{1}$, CAMILA GONÇALVES LENCI ${ }^{2}$, ANTONIO FIGUEIRA $^{3}$ \\ and DÉBORA DE QUEIROZ TAVARES ${ }^{2,4}$
}

(received: May 17, 2007; accepted: February 21, 2008)

\begin{abstract}
Localization of the cotyledon reserves of Theobroma grandiflorum (Willd. ex Spreng.) K. Schum., T. subincanum Mart., T. bicolor Bonpl. and their analogies with T. cacao L.). Cotyledon mesophyll cell morphology and lipid and protein synthesis of $T$. grandiflorum, $T$. subincanum and T. bicolor were analyzed and compared with $T$. cacao. These species possess foliar cotyledons folded around the hypocotyl radicle axis, typical of Sterculiaceae. Fruit size, morphology and weight are very distinct amongst the four species and so are the respective seeds. The main axis of the T. grandiflorum and T. bicolor seeds measured about $30 \mathrm{~mm}$, while T. subincanum and T. cacao seeds measured $17 \mathrm{~mm}$ and $26 \mathrm{~mm}$ respectively. The seed weights of T. grandiflorum, T. bicolor, T. subincanum and T. cacao were $11.6 \mathrm{~g}, 9.4 \mathrm{~g}, 2.1 \mathrm{~g}$ and $3.0 \mathrm{~g}$, respectively. The cotyledon mesophylls of the four species contained mainly polysaccharides and lipid-protein reserve cells. Theobroma cacao, T. grandiflorum and T. subincanum were composed of greater than $50 \%$ lipids. For the four species, lipid globules gradually accumulated adjacent to the cell wall, and these globules measured from 1 to $3 \mu \mathrm{m}$. TEM showed low-density proteins inside the central vacuole of the young mesophyll cells of $T$. cacao. The protein reserves of the mature cells were densely scattered amongst the lipid bodies, and a few starch granules occurred together with the cotyledon mesophyll of the four species. Polyphenolic cells were found throughout the mesophyll cells or aligned with the respective vascular bundles. Immature cells demonstrated the capacity to synthesize all these reserves, but gradually the pre-determined cells produced mainly lipid-protein reserves. Besides the unique characteristics of the T. cacao products, the lipid-protein synthesis capacities of T. grandiflorum, T. subincanum and T. bicolor suggest various possibilities for new industrialized food, pharmaceutical and cosmetic products.
\end{abstract}

Key words - comparative study, histology, reserves quantity, Theobroma

RESUMO - (Localização das reservas cotiledonares de Theobroma grandiflorum (Willd. ex Spreng.) K. Schum., T. subincanum Mart., T. bicolor Bonpl. e analogias com T. cacao L.). As células do mesofilo cotiledonar e respectivas sínteses lípide-protéicas de Theobroma grandiflorum, T. subincanum e T. bicolor são analisadas e comparadas ao T. cacao. As espécies mencionadas possuem os cotilédones foliáceos e redobrados em torno do eixo hipocótilo-radicular, típicos de Sterculiaceae; o tamanho dos frutos e também a morfologia, o peso e as respectivas sementes são distintos entre as quatro espécies. As sementes de T. grandiflorum e T. bicolor medem $30 \mathrm{~mm}$ no eixo principal, enquanto em T. subincanum e T. cacao medem $17 \mathrm{~mm}$ e $6 \mathrm{~mm}$, respectivamente e nesta mesma ordem pesam 11,6 g, 9,4 g, 2,1 g e 3,0 g. Os mesofilos cotiledonares contêm células com reservas polissacárides e lípide-proteicas. Theobroma cacao, T. grandiflorum e T. subincanum contêm acima de 50\% de lipídeos. Nas quatro espécies, os glóbulos lipídicos acumulam-se gradualmente, adjacentes à parede celular e medem entre 1 a $3 \mu \mathrm{m}$. A microscopia eletrônica de transmissão mostrou a precipitação pouco densa das proteínas no vacúolo central das células jovens do mesofilo de T. cacao. Nas células maduras, a proteína de reserva está densamente entremeada por glóbulos lipídicos; poucos grãos de amido ocorrem no mesofilo cotiledonar destas quatro espécies. As células polifenólicas estão dispersas no mesofilo cotiledonar ou alinhadas próximas ao feixe vascular. As células imaturas demonstraram capacidade de síntese de todas as reservas, mas gradualmente as células predeterminadas, produzem principalmente reservas lípide-proteicas. Não obstante a característica única dos reconhecidos produtos de $T$. cacao, a capacidade de síntese lípide-proteica do T. grandiflorum, T. subincanum e T. bicolor sugerem novas possibilidades para a indústria de alimentos, produtos farmacêuticos e cosméticos.

Palavras-chave - estudo comparativo, histologia, reservas, Theobroma

\footnotetext{
1 .

Instituto Adolfo Lutz, R. São Carlos, 720 V. Industrial. 13035-420 Campinas, SP-Brazil.

2. Universidade Estadual de Campinas, Faculdade de Engenharia de Alimentos, Departamento de Alimentos e Nutrição, CP 6121, 13083862 Campinas, SP-Brazil.

3. Universidade de São Paulo - Centro de Energia Nuclear na Agricultura, CP 96, 13400-970 Piracicaba, SP-Brazil

4.
}

\section{Introduction}

All Theobroma species present the same chromosome number: $2 n=2 \mathrm{x}=20$ (Muñoz 1948). The botanical classification of Theobroma into sections was defined according to the vegetative and morphological aspects of the trees, fruits and seeds (Cuatrecasas 1964), and 
the comparative seed morphology of $T$. grandiflorum (Willd. ex Spreng.) K. Schum, T. subincanum Mart., T. bicolor Bonpl. as compared to $T$. cacao L. was still necessary. The genetic polymorphism has been studied by Figueira et al. (1994), Silva et al. (2001) and Silva \& Figueira (2005). Theobroma contains 22 species classified into six sections (Cuatrecasas 1964), which have great importance as a gene reservoir for cacao improvement (Gilabert-Escrivá et al. 2002).

The full development of chocolate flavour requires fermentation and roasting of the $T$. cacao seeds (Voigt et al., 1995). Theobroma grandiflorum seeds are also fermented and roasted to achieve the "cupulate" flavour (Venturieri \& Aguiar 1988). Theobroma cacao seeds contain 53\% fats (Pires et al. 1998) and $15 \%$ to $20 \%$ protein on a dry weight basis. The protein fraction is composed mainly of albumin (52\% of total protein) and globulins (43\%) (Biehl et al. 1982, Spencer \& Hodge 1992, Voigt et al. 1993, 1995). Other Theobroma species contain higher fat and protein levels (Silva et al. 2001, Gilabert-Escrivá et al. 2002). Biehl et al. (1977, 1982) analysed the evolution of proteins from mature seeds in T. cacao during germination and fermentation. It has been proposed that during fermentation, $T$. cacao seed storage proteins are degraded by endo- and exo-proteases to oligopeptides, which react during roasting with other flavour precursors, such as sugars and polyphenols, to develop the full chocolate flavour (Voigt et al. 1995). It would be interesting to test the vicilins (Whitlock \& Baum 1999) from other Theobroma species in comparative fermentation studies, to elucidate the role of vicilin in the development of chocolate flavour. Reisdorff et al. (2004) characterized the activities of proteolytic enzymes (aspartic endopeptidase and carboxypeptidase) and storage seed globulins from T. grandiflorum and T. bicolor, observing small differences in the metabolic and biochemical pathways as compared to T. cacao. These three species are still being timidly exploited for human purposes. The development of chocolate-like products from these species could potentially be achieved by adapting the fermentation procedures to the particular biochemical cotyledon features of T. grandiflorum, T. subincanum and T. bicolor seeds. In this study we present the first simultaneous analysis and comparison of these three species with T. cacao in terms of early reserve synthesis, and synthesis of cotyledon protein, lipid and polyphenols.

\section{Material and methods}

Theobroma grandiflorum, T. subincanum, T. bicolor and $T$. cacao seeds were obtained from mature fruits from the germplasm collection of the "Comissão Executiva do Plano da Lavoura Cacaueira - Ceplac", located in Marituba, Pará ( $\left.1^{\circ} 12^{\prime} \mathrm{S} ; 4^{\circ} 30^{\prime} \mathrm{W}\right)$, Brazil and also from Itabuna, Bahia (1448' S; 39¹8' W), Brazil.

The analysis employed two mature fruits and a third one beginning to mature and 12 seeds from each species. A further five large mature T. cacao fruits from Itabuna were also employed. The cotyledons were split into two halves. One half was employed for microscopic analysis and the other for chemical analysis.

The cotyledons were fixed (2\% glutaraldehyde and $4 \%$ paraformaldehyde), included in glycol methacrylate, and prepared for the morphological and histochemical study using light microscopy (FM) (OBrien \& McCully 1981). Histological preparations for Scanning Electronic Microscopy (SEM) and Transmission Electronic Microscopy (TEM) were prepared according to Harris (1991).

The total lipid contents were determined by the Soxhlet method (963.15 AOAC 1997) based on both ground and freeze-dried samples. The proteins were determined using the Kjeldahl method (970.22 AOAC 1997) using a conversion factor of 5.4. Polyphenols were determined by spectrophotometry (Marigo 1973).

\section{Results and discussion}

The seed genetics of this collection (CEPLAC) have been studied by Silva et al. (2001), who established the total seed protein profile and random amplified polymorphic DNA (RAPD). Silva \& Figueira (2005) analysed the trypsin inhibitor gene of the same collection.

The Theobroma grandiflorum, T. subincanum, T. bicolor and T. cacao fruits were almost ellipsoids (figures 1A-4A) and displayed variation in seed size (figures 1B4B). The cotyledon mesophylls of these species showed the following genus characteristics: a flattened mesophyll, which was always densely folded around the hypocotyl radicle axis and whitish mesophylls, or darker if anthocyanin synthesis was abundant (figures 1-4). The cotyledon foliar morphology was evident from the vascular bundles scattered around the entire mesophyll tissue (Barroso et al. 1999, Silva et al. 2001). Before germination, the thickness of the cotyledon mesophyll was $0.7 \mathrm{~mm}$ in $T$. grandiflorum and T. subincanum (figures 1B-2B), reaching $1.4 \mathrm{~mm}$ in T. bicolor and $T$. cacao (figures 3B-4B). The cotyledonary mesophylls of T. bicolor and T. cacao were thicker than the others and showed less folds. The name T. bicolor was well suited to this plant because its young cotyledons (figure 5A) sheltered a translucent, detachable tissue amongst their folds, which was homogeneous parenchyma containing no reserve substances (figure 5B).

The seeds of $T$. grandiflorum and $T$. bicolor were heavier in relation to the T. subincanum and T. cacao 

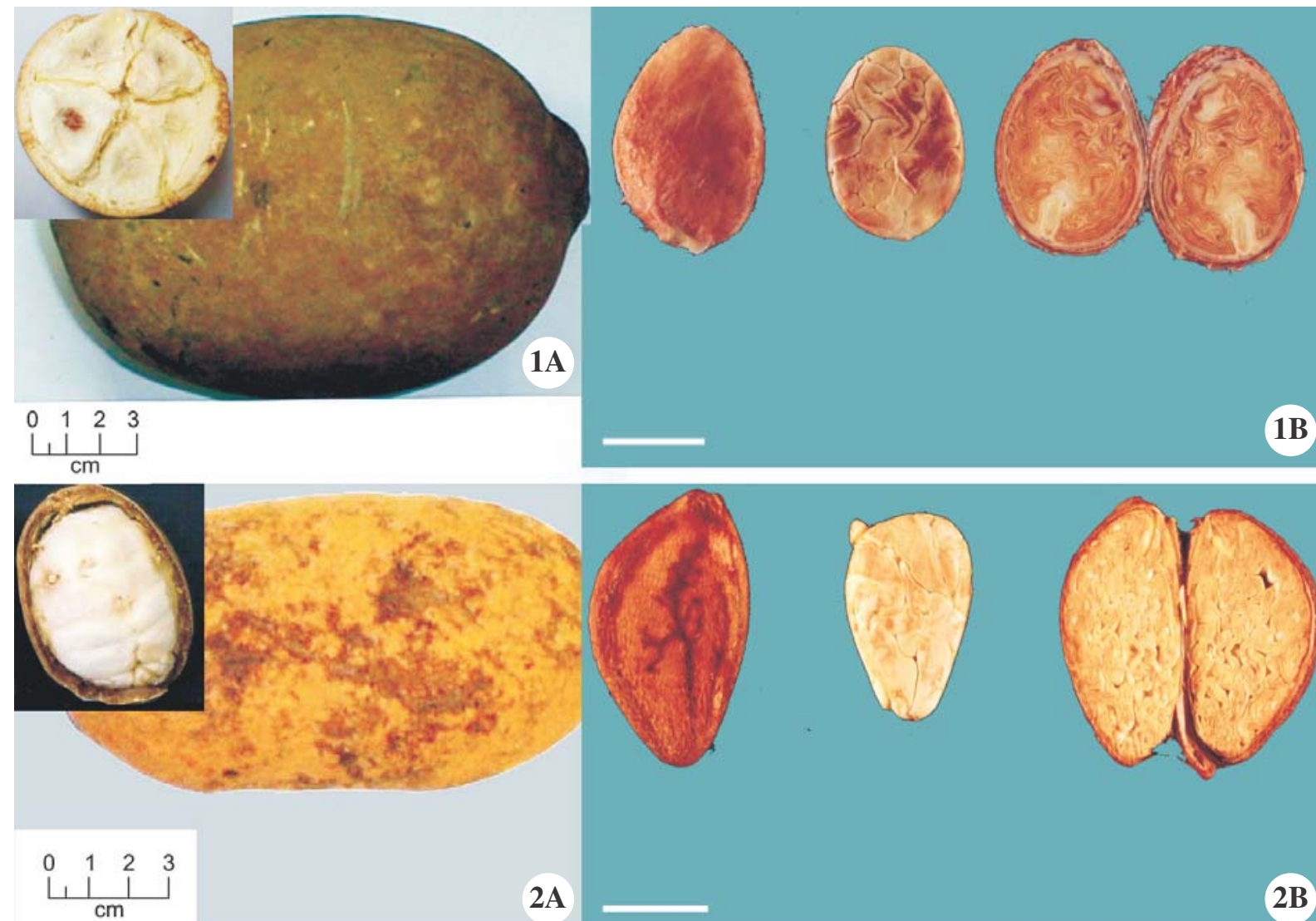

2A
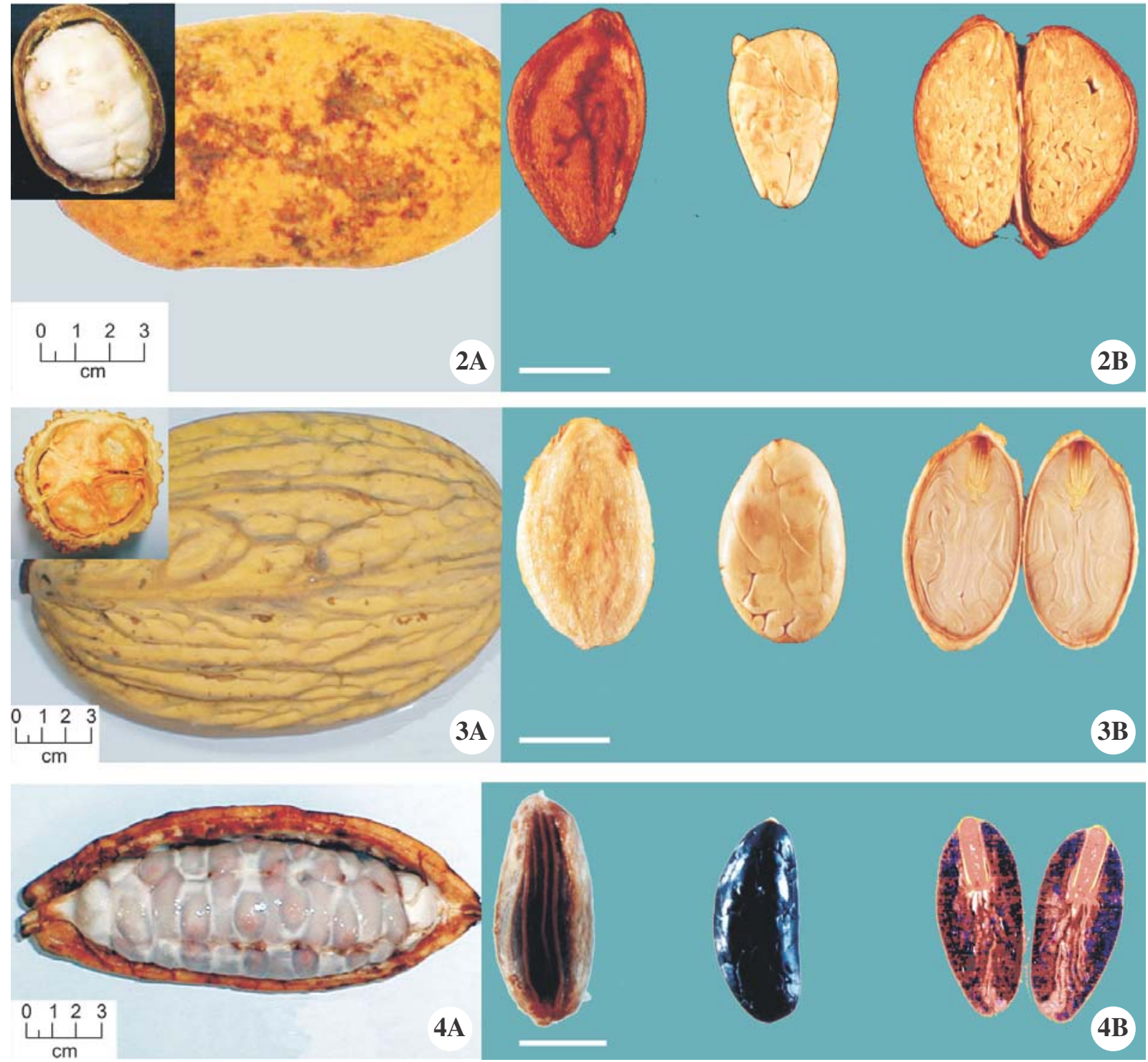

Figures 1-4. Fruits and their seeds: 1. Theobroma grandiflorum. 2. T. subincanum. 3. T. bicolor. 4. T. cacao. The Theobroma genus displays significant fruit shape diversity. Variations in ellipsoid fruit shape (1A-4A) and respective seed sizes (1B-4B) are shown. T. grandiflorum (1B) and T. subincanum (2B) cotyledons are thinner and larger than in T. bicolor (3B). Bars $=$ $10 \mathrm{~mm}(1 \mathrm{~B}, 2 \mathrm{~B}, 3 \mathrm{~B}$ and $4 \mathrm{~B})$. 
seeds (table 1). The seed weights of T. cacao were variable, due to the ellipsoidal shape of the fruit. However, as described by Silva \& Figueira (2005), in fact the T. cacao varieties from CEPLAC displayed distinct seed shapes amongst the varieties.

Figures 5-8 display the mesophyll characteristics found using FM. The species studied initially synthesized mucilage, starch granules, lipid and protein bodies concomitantly (figures 5-7). Intense mucilage synthesis occurred in all the seed cells and also in other fruit tissues.
Table 1. Average size and weight of the seeds of Theobroma subincanum, T. cacao, T. bicolor and T. grandiflorum.

\begin{tabular}{lcr}
\hline Species & Size $^{*}(\mathrm{~mm})$ & Weight** $(\mathrm{g})$ \\
\hline Theobroma subincanum & $17 \times 11$ & $2.1 \pm 0.2$ \\
T. cacao & $26 \times 13$ & $3.0 \pm 0.2$ \\
T. bicolor & $30 \times 24$ & $9.4 \pm 1.1$ \\
T. grandiflorum & $31 \times 24$ & $11.6 \pm 2.8$ \\
\hline
\end{tabular}

* longitudinal and transversal axis; $* *$ values: average \pm standard deviation.
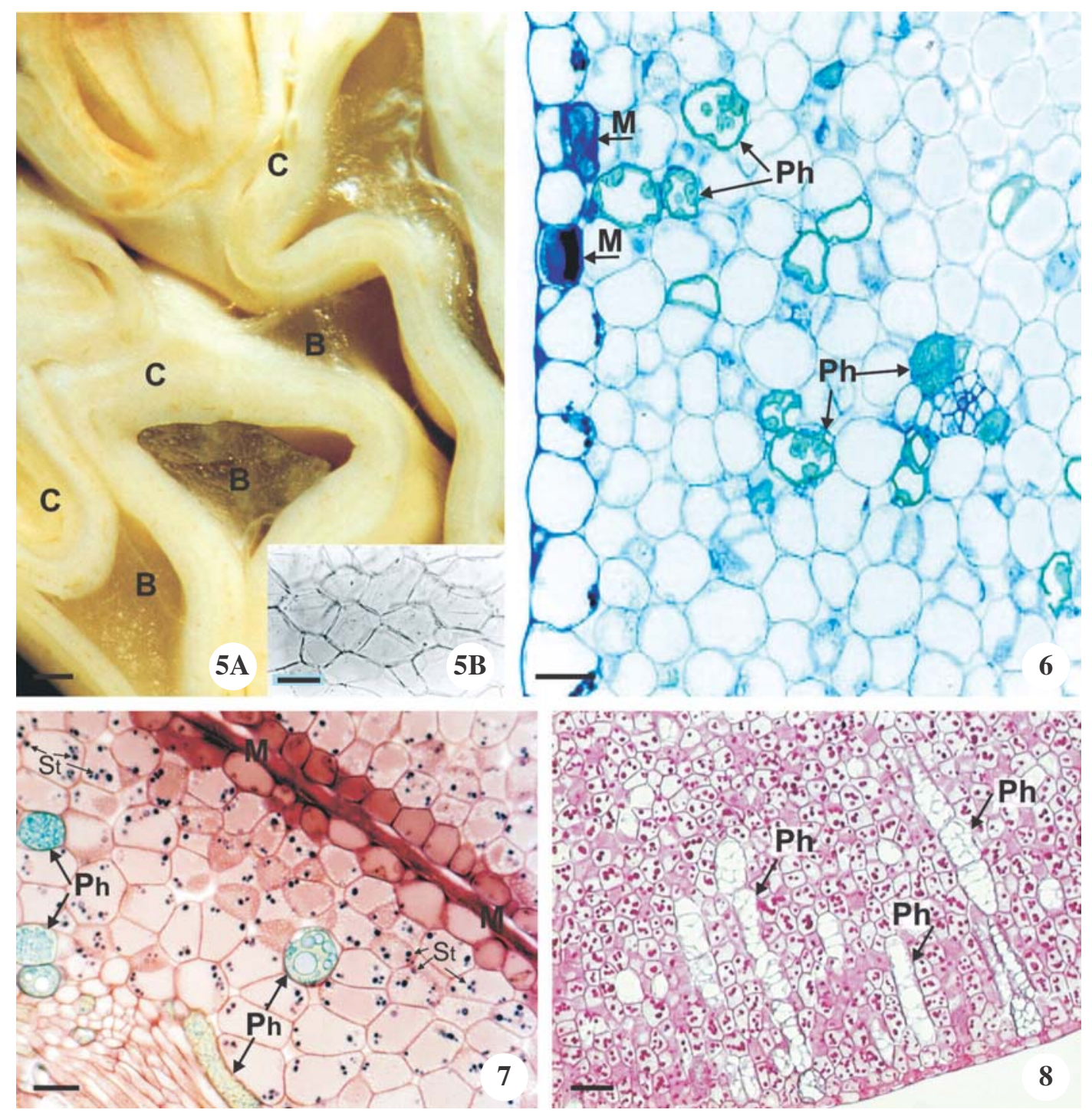

Figures 5-8. FM-Cotyledon mesophyll. 5A-5B. Theobroma bicolor. This fresh folded cotyledon (5A) is concealing a translucid tissue (B) characteristic of T. bicolor. This non-differentiated tissue is the original seed suspending-axis (5B). 6. T. subincanum. Toluidine Blue ( $\mathrm{pH} 4)$ staining mucilage and phenolic deposits. 7. T. grandiflorum. I/KI reaction staining of the mesophyll. Mucilage, small starch granules and the phenolic deposits. 8. T. cacao. PAS/Schiff stain. Starch granules and mesophyll cells are red. It is characteristic to $T$. cacao these rolls of phenolic cells toward the mesophyll border. $(\mathrm{B}=$ translucid tissue; $\mathrm{C}=$ cotyledon; $\mathrm{M}=$ mucilage; $\mathrm{Ph}=$ polyphenolic cells; $\mathrm{St}=$ starch granules $) . \mathrm{Bars}=10 \mathrm{~mm}(5 \mathrm{~A}), 10 \mu \mathrm{m}(5 \mathrm{~B}), 50 \mu \mathrm{m}(6,7)$, $5 \mu \mathrm{m}(8)$. 
The synthesis of acid and neutral polysaccharides, which filled the epidermis and its mesophyll cells was demonstrated using Toluidine Blue for T. subincanum, (figure 6) or the Schiff PAS/Reactive stain for T. cacao (figure 8).

The T. cacao cotyledon showed a great amount of idioblast polyphenolic cells interspersed with the mesophyll cells. A peculiarity of the mature seeds of both T. cacao and T. grandiflorum (Martini 2004) was the presence of rows of polyphenolic cells displayed perpendicular to the cotyledon mesophyll edge (figure 8).

The cotyledon mesophylls of the four species presented protein, lipid and polyphenols (table 2) and the syntheses of these components followed a maturation gradient inside the fruit. Young mesophyll cells started accumulating protein reserves in their central area (figures 9-10) and also lipid droplets inside the cytoplasm, which accumulated adjacent to the cell walls (figure 11). These figures show intercellular spaces, which are characteristics of T. cacao and of other species from the same genus, described previously by Brooks \& Guard (1952). We have also previously shown that $T$. subincanum displays large and a great number of intercellular spaces (Martini, 2004). In fresh sections of the $T$. subincanum cotyledon mesophyll cells were dissociable under gentle mechanical compression on a slide. We suggest that the weak union between the $T$. subincanum cells promoted natural mucilage storing spaces, a phenomenon already described to T. speciosum Willd. ex Spreng. (Martini et al. 2003). We have associated the same predominance of mucilage with smaller amounts of polyphenols in T. bicolor and furthermore we demonstrated the accumulation of great pools of mucilage in the middle of the mesophyll cells in T. speciosum and the poorer content of polyphenols (Martini et al. 2003).

When close to maturity the lipid and protein reserves prevailed over the cell structure components, as, for instance, the starch granules. The protein reserves in $T$. cacao, T. bicolor and T. grandiflorum were very expressive (table 2), which explains the incipient South

Table 2. Concentrations of the main seed reserves (dry basis, $\mathrm{mg} \mathrm{g}^{-1}$ ). Values of triplicates, average \pm standard deviation.

\begin{tabular}{lrcr}
\hline Sample & \multicolumn{1}{c}{ Protein } & Lipid & Polyphenols \\
\hline Theobroma cacao & $143.5 \pm 1$ & $492.4 \pm 6$ & $79.9 \pm 6$ \\
T. subincanum & $94.8 \pm 5$ & $598.8 \pm 4$ & $55.2 \pm 2$ \\
T. bicolor & $190.7 \pm 2$ & $308.6 \pm 8$ & $5.0 \pm 1$ \\
T. grandiflorum & $129.5 \pm 1$ & $542.2 \pm 0$ & $42.7 \pm 2$ \\
\hline
\end{tabular}

American industrialization of $T$. bicolor and $T$. grandiflorum in addition to that of T. cacao.

Lipids were definitely the main cell reserves in the four species (table 2). The lipid globules, with diameters ranging from 1 to $3 \mu \mathrm{m}$, were found in a spacial association with the protein reserves (figures 9-10, 12,13). When fresh mesophylls were submitted to temperatures above $28{ }^{\circ} \mathrm{C}$, the lipid globules of those live cells quickly coalesced. Figure 11 (left side) displays the characteristic
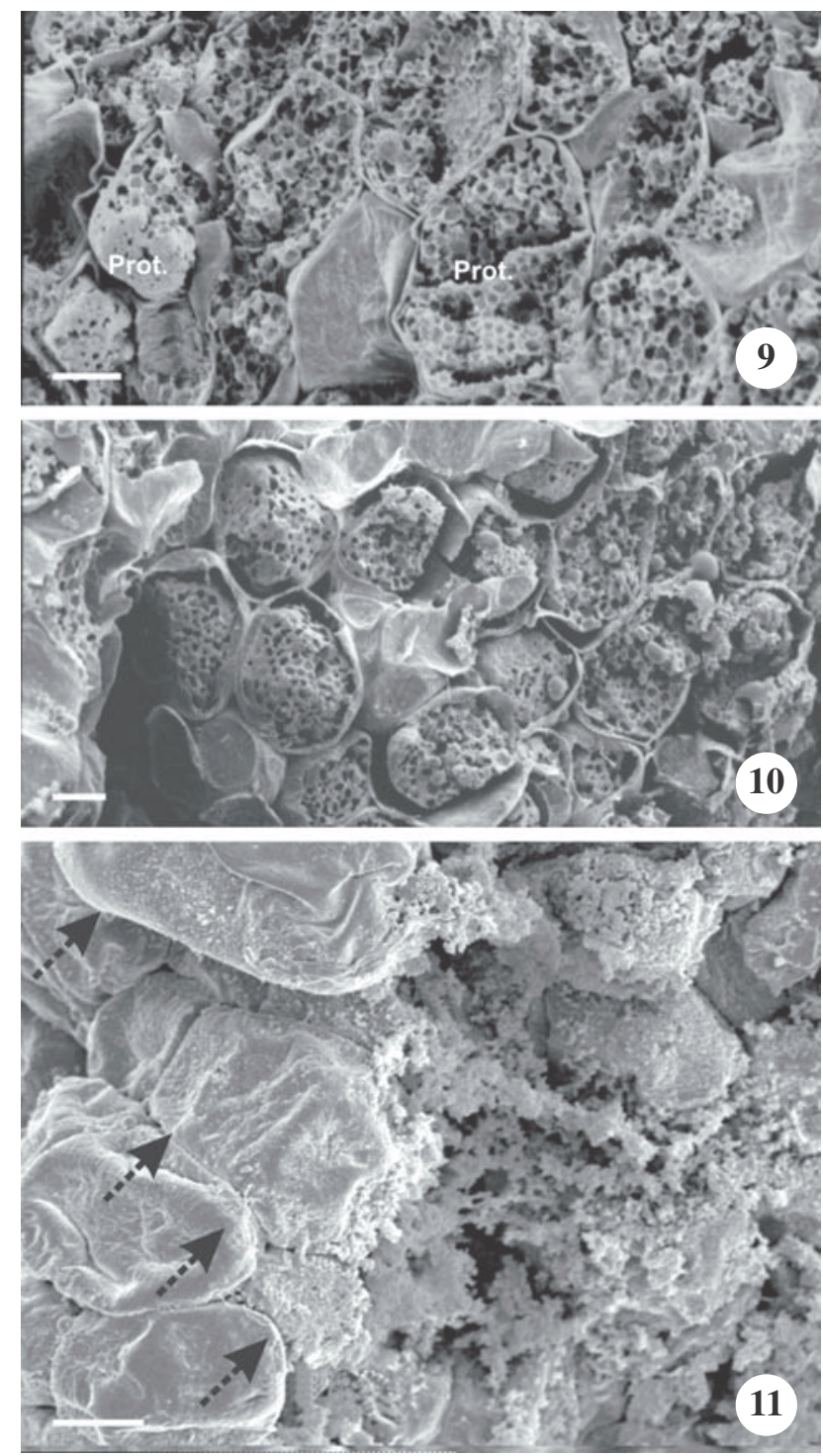

Figures 9-11. SEM-Lipid and protein reserves. 9. T. cacao. The opened mesophyll cells are exposing protein reserves; the sieve-like structures are due to protein deposition around lipid droplets. 10. T. bicolor, similar protein and lipid mass from figure 9. 11. T. grandiflorum. The four closed cells on left side (arrows) show the loose association of the mesophyll cell tissue. A mass of leaked proteins is seen on the right. $($ Prot $=$ protein reserves). Bars $=10 \mu \mathrm{m}(9,11), 20 \mu \mathrm{m}(10)$. 
loose association of the T. grandiflorum mesophyll cells, as mentioned above for T. speciosum. During fotonic microscopy at $15{ }^{\circ} \mathrm{C}$, the fresh cotyledons of $T$. grandiflorum, T. bicolor and T. subincanum preserved the lipid globules, which were evident from their fluorescence (Martini 2004). In fact, due to the interaction of the lipid globules with the protein reserves, it was not possible to define the oleosin membrane (figures 14-17). Although Guilloteau et al. (2003) reported the existence of two classes of oleosins in T. cacao, the rapid coalescence amongst the lipid bodies, when exposed to temperatures above $28{ }^{\circ} \mathrm{C}$ (fresh histological sections), did not help to confirm the existence of the oleosin membrane enclosure.

Gilabert-Escrivá et al. (2002) determined the fatty acids and triacylglycerols of the same species from the same geographical location and demonstrated the predominance of oleic and stearic acids. These authors stressed the higher palmitic acid concentration in $T$. cacao as compared to the other three species.
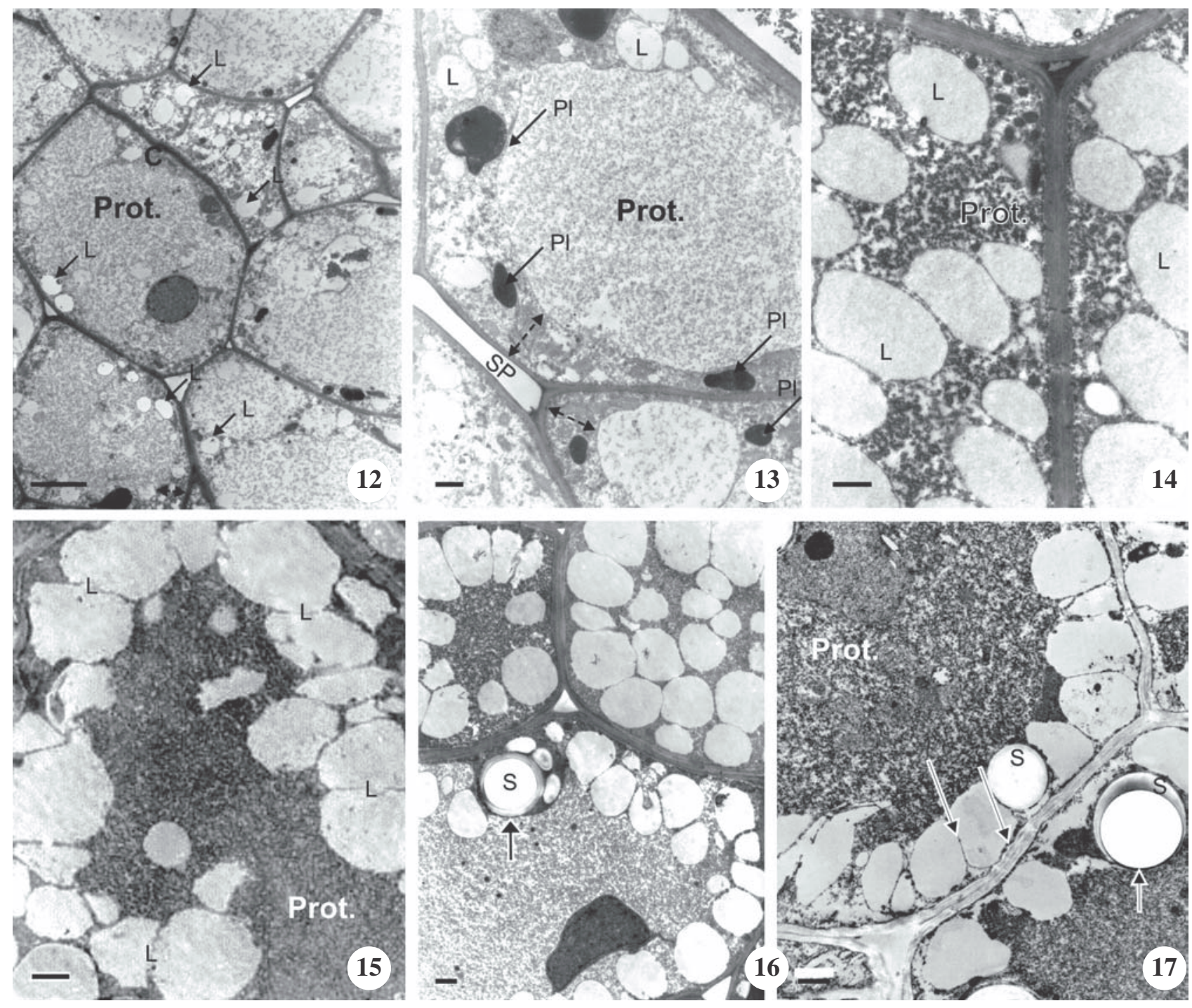

Figures 12-17 TEM-Mesophyll of four Theobroma species. 12-13. Theobroma cacao, immature mesophyll. 12. The initial phase of reserve protein synthesis it is inside the large central vacuole and in the peripheral cytoplasm are visible appearance the first lipid bodies. 13. The plastid structure became enlarged due to polyphenols synthesis. Intercellular spaces are conspicuous. 14-17. Mature mesophyll. 14. T. cacao. Protein and lipid synthesis characterize this mesophyll. 15. T. grandiflorum. Lipid globules are coalescing faster than in the other three species. 16. T. subincanum. A plastid shelters the external halo of a starch granule. 17. T. bicolor. Mature cells have the protein reserves are surrounding the lipid globules (arrows) and two starch granules only contains the external part of the granule. $(\mathrm{C}=$ cytoplasm; $\mathrm{L}=$ lipid; $\mathrm{Pl}=$ plastid; Prot $=$ protein reserves; $\mathrm{S}=$ starch granule; $\mathrm{SP}=$ intercellular spaces). Bars $=4 \mu \mathrm{m}(12), 1 \mu \mathrm{m}(13-16), 2 \mu \mathrm{m}(17)$. 
The common cotyledon mesophyll feature of the four species was the large, densely folded mesophyll. In all these species lipid synthesis and storage prevailed over that of proteins.

The main purpose of the present study was to focus on the synthesis of the reserves from the first signals of cell deposition up to fruit maturity. Besides lipids, the younger mesophyll cells were shown to synthesize a wide variety of reserves, such as proteins, mucilage, starch and polyphenols. Despite the differences in quantity and important physicochemical distinctions between these reserves, mesophyll morphology was found to be somewhat similar, especially between $T$. cacao and $T$. grandiflorum.

Our analysis of fresh tissue and microscopic (FM, SEM and TEM) tissue samples did not provide evidence of oleosin membrane in those species.

The amount of polyphenols was relatively high in T. cacao, followed by T. subincanum and T. grandiflorum; however this is not a common feature in the other species.

Acknowledgments - We would like to thank Yara Fagnani Honório for her technical support.

\section{References}

AOAC. Official methods of analysis of AOAC International. 1997. (P. Cunniff, ed.), AOAC Gaithersburg, v.1-2.

BARROSO, G.M., MORIM, M.P., PEIXOTO, A.L. \& ICHASO, C.L.F. 1999. Frutos e sementes: morfologia aplicada à sistemática de dicotiledôneas. Universidade Federal de Viçosa, Viçosa.

BIEHL, B., PASSERN, U. \& PASSERN, D. 1977. Subcellular structures in fermenting cocoa beans. Effect of aeration and temperature during seed and fragment incubation. Journal of the Science of Food and Agriculture 28:41-52.

BIEHL, B., WEWETZER, C., PASSERN, D. 1982. Vacuolar (storage) proteins of cocoa seeds and their degradation during germination and fermentation. Journal of the Science of Food and Agriculture 33:1101-1109.

BROOKS, E.R. \& GUARD, A.T. 1952. Vegetative anatomy of Theobroma cacao. Botanical Gazette 113:44-54.

CUATRECASAS, J. 1964. Cacao and its allies: a taxonomic revision of the genus Theobroma. Contributions from the United State National Herbarium 35:379-614.

FIGUEIRA, A., JANICK, J. \& BEMILLER, J.N. 1994. Partial characterization of cacao pod and stem gums. Carbohydrate Polymers 24:133-138.

GILABERT-ESCRIVÁ, M.V., GONÇALVES, L.A.G., SILVA, L.R.S. \& FIGUEIRA, A. 2002. Fatty acid and triacylglycerol composition and thermal behaviour of fats from seeds of Brazilian Amazonian Theobroma species. Journal of the Science of Food and Agriculture 82:1425-1431.
GUILLOTEAU, M., LALOI, M., BLAIS, D., CROUZILLAT, D. \& MC CARTHY, J. 2003. Oil bodies in Theobroma cacao seeds: cloning and characterization of cDNA encoding the 15.8 and $16.9 \mathrm{kDa}$ oleosins. Plant Science 164:597-606.

HARRIS, J.R. 1991. Electron microscopy in Biology: a practical approach. Oxford University Press, New York.

MARIGO, G. 1973. Sur une méthode de fractionnement et d'estimation des composés phénoliques chez les végétaux. Analusis 2:106-110.

MARTINI, M.H. 2004. Caracterização das sementes de seis espécies de Theobroma em relação ao Theobroma cacao L. Tese de Doutorado, Universidade Estadual de Campinas, Campinas.

MARTINI, M.H., LENCI, C.G., \& TAVARES, D.Q. 2003. Mucilage pockets in cotyledon tissue of Theobroma speciosum. Acta Microscopica 1:65-69.http://www. sbmm.org.br/actar/html/trabalhos/12.pdf. (acesso em 23/01/2004).

MUÑOZ, J.M.O. 1948. Estudios cromosomicos en el genero Theobroma. IICA, Turrialba.

O'BRIEN, T.P. \& MCCULLY, M.E. 1981.The study of plant structure: principles and selected methods. Termarcarphy Pty. Ltd., Melbourne

PIRES, J.L., CASCARDO, J.C.M., LAMBERT, S.V., FIGUEIRA, A. 1998. Increasing cocoa butter yield through genetic improvement of Theobroma cacao L.: Seed fat content variability, inheritance, and association with seed yield. Euphytica 103:115-121.

REISDORFF, C., ROHSIUS, C., SOUZA, A.D.C., GASPAROTTO, L. \& LIEBEREI, R. 2004. Comparative study on the proteolytic activities and storage globulins in seeds of Theobroma grandiflorum (Willd. ex Spreng.) Schum. and Theobroma bicolor Humb. Bonpl., in relation to their potential to generate chocolate-like aroma. Journal of the Science of Food and Agriculture 84:693-700.

SILVA, C.R.S. \& FIGUEIRA, A. 2005. Phylogenetic analysis of Theobroma (Sterculiaceae) based on Kunitz-like trypsin inhibitor sequences. Plant Systematics and Evolution 250:93-104.

SILVA, C.R.S., FIGUEIRA, A.V.O. \& SOUZA, E.C.A.S. 2001. Diversidade no gênero Theobroma. In Melhoramento genético do cacaueiro (L.A.S. Dias, ed.) FUNAPE-UFG, Goiania, p.49-80.

SPENCER, M.E. \& HODGE, R. 1992. Cloning and sequencing of a cDNA encoding the major storage proteins of Theobroma cacao. Planta 186:567-576.

VENTURIERI, G.A. \& AGUIAR, J.P.L. 1988. Composição do chocolate caseiro de amêndoas de cupuaçu Theobroma grandiflorum (Willd. ex Spreng.) Schum. Acta Amazônica 18:3-8.

VOIGT, J., BIEHL, B., KAMARUDDIN, S. \& WAZIR, S. 1993. The major seed proteins of Theobroma cacao L. Food Chemistry 47:145-151. 
VOIGT, J., KAMARUDDIN, S., HEINRICHS, H., WRANN, D., SENYUK, V. \& BIEHL, B. 1995. Developmental stage-dependent variation of the levels of globular storage protein and aspartic endoprotease during ripening and germination of Theobroma cacao L. seeds. Journal Plant Physiology 145:199-307.
WHITLOCK, A.B. \& BAUM, D.A. 1999. Relationships of Theobroma and Herrania (Sterculiaceae) based on sequences of the nuclear gene vicilin. Systematic Botany 24:128-138. 